Pak. j. sci. ind. res. Ser. B: biol. sci. 201154 (2) 88-92

\title{
Effect of Added Modified Water Chestnut (Trapa bispinosa) Starch on Physical and Sensory Properties of Yeast Leavened Breads
}

\author{
Zubala Lutfi*, Ayesha Siddique and Abid Hasnain \\ Department of Food Science \& Technology,University of Karachi, Karachi-75270, Pakistan
}

(Received May 5, 2010; revised September 4, 2010; accepted October 18, 2010)

\begin{abstract}
The effects of using different concentrations of chemically and physically modified water chestnut (Trapa bispinosa) starch (WCS) on loaf weight, volume and specific volume of yeast leavened bread were studied. The highest loaf weight was obtained by the addition of native water chestnut starch at $3 \%$ concentration, while the opposite effect was observed regarding the loaf volume and specific volume. The highest loaf volume and the specific volume was obtained on addition of WCS, pregelatinized and acetylated (pga), at 1\% concentration. Maximum mean score (7.8) was obtained by native water chestnut starch at concentration of $5 \%$ and minimum mean score was obtained by pgaWCS at $1 \%$ concentration with respect to the taste of bread. Regarding the texture, the maximum mean score (7.5) was that of the bread containing 5\% pga (pregelatinized and acid thinned) WCS and minimum mean score (4), that of the bread containing $5 \%$ acetylated water chestnut starch.
\end{abstract}

Keywords: water chestnut, loaf weight, loaf volume, specific volume

\section{Introduction}

Starch is the most abundant reserve carbohydrate storage in plants. It is found in many different plant organs including seeds, fruits, tubers and roots. Starches are well known for their properties such as, gelation, gelatinization, pasting, solubility, swelling, paste clarity and freeze thaw stability, which enhances the functional properties of the food products. The high carbohydrate content of water chestnut (Trapa bispinosa) makes it powerful source of starch for the industrial and domestic uses. The molecular size and shape of the amylose of the water chesnut starch as well as the extent of its amylose and amylopectin association are different from those of mung bean starch and these may play important role in starch retrogradation (Hizukuri et al., 1988; Zobel, 1984).

Starch is a versatile and useful polymer not only because it is a cheap natural material but also because of the ease with which its physico-chemical properties can be altered through chemicals or enzyme modification and/or physical treatment.

Strengthening of bread crumb-structure, improvement in the digestibility of bread and, improvement in dough and bread yields are major advantages achieved by adding modified starches (Stear, 1990).

*Author for correspondence; E-mail: zubala_lutfi7@gmail.com
Modified starches, particularly highly cross linked and substituted pre-gelatinized starches, help in binding the moisture present in the baked foods, thus providing improved tenderness in the final product and contributing to the development of a fine, uniform cell structure, better paste clarity and stability, increased resistance to retrogradation and freeze thaw stability (Glover et al., 2006; BeMiller, 1997).

The objective of the present study is to overcome the structural and textural problems encountered in bread making by addition of modified starches in the formulations.

\section{Materials and Methods}

Materials. Dried water chestnut, all purpose flour, sugar, salt $(\mathrm{NaCl})$, yeast and shortening were purchased from local markets of Karachi, Pakistan.

Starch was extracted from dried water chestnut and modified physically and chemically. Four different types of starches, native, acid-thinned, acetylated, double modified i.e. pregelatinized followed by acid-thinning and pregelatinization followed by acetylation, starch were used in bread formulations.

Isolation of starch. The selected dehydrated water chestnuts were comminuted and $1 \mathrm{~kg}$ of sample was mixed with $2 \mathrm{~L}$ of water, while maintaining $\mathrm{pH} 9.0$ by adding $0.2 \%$ sodium hydroxide solution. The slurry 
was filtered through 100 and 170 mesh sieves and centrifuged at $3000 \mathrm{rpm}$ using a BECKMAN COULTER Allegra $^{\mathrm{TM}} \mathrm{X}-22$ centrifuge. The residue was washed with water to remove colour and then air dried in oven at $45 \pm 1{ }^{\circ} \mathrm{C}$ to $13 \%$ moisture content (Lutfi and Hasnain, 2009; Tulyathan et al., 2005).

Proximate analysis. Standard methods of AOAC (2000) were adopted for estimating moisture, ash, crude fibre, protein and fat content.

Purification of water chestnut starch. Purity (on dry basis), expressed as total starch percentage, was calculated as: $100-$ (crude proteins $(\mathrm{N} \times 6.21)+$ ash + crude fiber + fatty material). Percent yield was calculated using the equation: (starch weight/grains weight) $\times 100$ (Sira and Amaiz, 2004)

Single modification of water chestnut starch. Pregelatinization. Pregelatinization method as described by Lutfi and Hasnain (2009) and Waliszewski et al. (2003) was used.

Acetylation. The acetylation was carried out by the method as stated by Lutfi and Hasnain (2009) and Sathe Sabrnkhe (1981).

Acid thinning. The method of Lawal (2004) was employed.

Double modification of water chestnut starch. Pregelatinization followed by acid Thinning. Pregelatinization was carried out by the method of Waliszewski et al. (2003) and acid thinned as stated by Lawal (2004).

Pregelatinization followed by acetylation. Pregelatinization was carried out using the method of Waliszewski et al. (2003) and acetylated by the method of Sathe and Salunkhe (1981).

Preparation of flour mixtures. The blending ratios (\%) of native and modified wheat flours and water chestnut starch used in the mixture were 99:01, 98:02, 97:03, 96:04, 95:05, 94:06, 93:07, 92:08, and 91:09. The ratio in the control was 100:0.

Preparation of breads. Breads were made according to the American Association of Cereal Chemistsapproved methods, $10-10 \mathrm{~B}$ (AACC, 2000). All the breads, except control, were supplemented with $1 \%$, $2 \%, 3 \%, 4 \%, 5 \%$ and $6 \%$ (flour weight basis) of modified and unmodified starch, each.

Physical measurements. The weights of bread samples were determined after sufficient cooling using digital balance ( $0.01 \mathrm{~g}$ accuracy) and the loaf volumes were determined using rapeseed displacement method. The specific volume of each loaf was then calculated as:

Specific volume $\left(\mathrm{cm}^{3} / \mathrm{g}\right)=($ loaf volume/ loaf weight $)$

Sensory evaluation of breads. Breads were evaluated on the basis of acceptability of their appearance, odour, flavour, texture and overall preference by a hedonic 9-point scale where 9 means the most liked and 1, the most disliked. Control bread was presented separately to all the panelists with the set point of 5 meaning average on the hedonic scale for comparison with other samples.

Statistical analysis. The results reported are means of triplicate determinations. The statistical analysis of the results was conducted by the analysis of variance (ANOVA) and LSD test using SPSS version 11.0 for Windows programme. Significant differences were reported for $\mathrm{P} \leq 0.05$.

\section{Results and Discussion}

Water chestnut starch contained $0.17 \%$ of ash, $0.1 \%$ of protein and $0.19 \%$ of fat, thus giving $99.54 \%$ pure starch. The values obtained were almost similar to those of the earlier studies on water chestnut starch (Lawal, 2004). Moisture content was $8.5 \%$; the moisture content plays a significant role in the flow and other mechanical properties, although it depends largely on the method, extent of drying and the humidity in the surrounding atmosphere.

The result of size-related parameters of the water chestnut yeast leavened bread are shown in Table 1. Loaf volume, weight and specific volume ranged from 483.63 to $798.43 \mathrm{~cm}^{3}, 139.88$ to $382.72 \mathrm{~g}$ and 1.38 to $5.68 \mathrm{~cm}^{3} / \mathrm{g}$, respectively. These values varied significantly $(\mathrm{P} \leq 0.05)$ with both the concentration and the modification of water chestnut starch. The bread with higher loaf weight and volume provides better economic effect at the retail end hence, the reduction in the loaf weight during baking is an undesirable economic quality for the bakers as the bread loaf with higher weight and volume is usually the choice of consumers believing that it has more substance for the same price. The specific volume, which is the ratio of the two properties, has been generally adopted in the literature as a more reliable measure of loaf size. Loaf volume is affected by proofing time (Zghal et al., 2002) as well as the quality and quantity of protein in the flour (Ragaee and Abdel-Aal, 2006), whereas loaf weight is basically determined by 
Table 1. Effect on loaf weight, loaf volume and specific volume by the addition of nWCS, aWCS, at WCS, pgWCS, pgatWCS and pgaWCS at 1\%, 2\%, 3\%, 4\%, $5 \%$, and $6 \%$ concentrations.

\begin{tabular}{|c|c|c|c|}
\hline Samples & $\begin{array}{l}\text { Loaf weight } \\
\text { (g) }\end{array}$ & $\begin{array}{l}\text { Loaf volume } \\
\left.\mathrm{cm}^{3}\right)\end{array}$ & $\begin{array}{l}\text { Specific volume } \\
\left(\mathrm{cm}^{3} / \mathrm{g}\right)\end{array}$ \\
\hline Control & $143.57^{\mathrm{a}}$ & $550.09^{\mathrm{a}}$ & $3.83^{\mathrm{a}}$ \\
\hline nWCS (1\%) & $143.8^{\mathrm{b}}$ & $544.7^{\mathrm{b}}$ & $3.79^{b}$ \\
\hline aWCS & $225.95^{\mathrm{c}}$ & $512.69^{c}$ & $2.27^{\mathrm{c}}$ \\
\hline atWCS & $157.26^{\mathrm{d}}$ & $597.98^{d}$ & $3.80^{\mathrm{d}}$ \\
\hline pgWCS & $152.54^{\mathrm{e}}$ & $535.23^{\mathrm{e}}$ & $3.51^{\mathrm{e}}$ \\
\hline pgatWCS & $145.73^{f}$ & $710.92^{f}$ & $4.88^{f}$ \\
\hline pgaWCS & $140.52^{\mathrm{g}}$ & $798.43^{\mathrm{g}}$ & $5.68^{\mathrm{g}}$ \\
\hline nWCS $(2 \%)$ & $143.58^{\mathrm{a}}$ & $583.69^{\mathrm{b}}$ & $4.07^{\mathrm{b}}$ \\
\hline aWCS & $202.48^{\mathrm{b}}$ & $541.18^{c}$ & $2.67^{\mathrm{c}}$ \\
\hline atWCS & $144.06^{\mathrm{c}}$ & $580.89^{d}$ & $4.03^{\mathrm{d}}$ \\
\hline pgWCS & $151.3^{\mathrm{d}}$ & $532.75^{\mathrm{e}}$ & $3.52^{\mathrm{e}}$ \\
\hline pgatWCS & $146.89^{\mathrm{e}}$ & $727.188^{f}$ & $4.95^{\mathrm{f}}$ \\
\hline pgaWCS & $139.88^{\mathrm{f}}$ & $772.84^{\mathrm{g}}$ & $5.53^{\mathrm{g}}$ \\
\hline nWCS $(3 \%)$ & $382.72^{b}$ & $528.63^{b}$ & $1.38^{\mathrm{b}}$ \\
\hline aWCS & $197.09^{c}$ & $536.22^{\mathrm{c}}$ & $2.72^{\mathrm{c}}$ \\
\hline atWCS & $150.42^{\mathrm{d}}$ & $596.9^{\mathrm{d}}$ & $3.97^{\mathrm{d}}$ \\
\hline pgWCS & $152.14^{\mathrm{e}}$ & $507.166^{\mathrm{e}}$ & $3.33^{\mathrm{e}}$ \\
\hline pgatWCS & $143.97^{\mathrm{f}}$ & $749.89^{f}$ & $5.21^{\mathrm{f}}$ \\
\hline pgaWCS & $141.2^{\mathrm{g}}$ & $735.44^{\mathrm{g}}$ & $5.21^{\mathrm{f}}$ \\
\hline nWCS (4\%) & $143.54^{b}$ & $565.12^{\mathrm{b}}$ & $3.94^{\mathrm{b}}$ \\
\hline $\mathrm{aWCS}$ & $196.72^{c}$ & $523.56^{\mathrm{c}}$ & $2.66^{\mathrm{c}}$ \\
\hline atWCS & $156.38^{d}$ & $581.35^{\mathrm{d}}$ & $3.72^{\mathrm{d}}$ \\
\hline pgWCS & $153.78^{\mathrm{e}}$ & $497.69^{\mathrm{e}}$ & $3.24^{\mathrm{e}}$ \\
\hline pgatWCS & $148.66^{\mathrm{f}}$ & $675.75^{\mathrm{f}}$ & $4.55^{\mathrm{f}}$ \\
\hline pgaWCS & $141.87^{\mathrm{g}}$ & $731.31^{\mathrm{g}}$ & $5.15^{\mathrm{g}}$ \\
\hline nWCS (5\%) & $143.49^{b}$ & $551.9^{\mathrm{b}}$ & $3.85^{\mathrm{b}}$ \\
\hline aWCS & $185.16^{\mathrm{c}}$ & $568.42^{\mathrm{c}}$ & $3.07^{\mathrm{c}}$ \\
\hline atWCS & $145.02^{\mathrm{d}}$ & $557.77^{\mathrm{d}}$ & $3.85^{\mathrm{b}}$ \\
\hline pgWCS & $148.47^{\mathrm{e}}$ & $483.63^{\mathrm{e}}$ & $3.26^{\mathrm{d}}$ \\
\hline pgatWCS & $141.79^{f}$ & $691.68^{\mathrm{f}}$ & $4.88^{\mathrm{e}}$ \\
\hline pgaWCS & $146.22^{\mathrm{g}}$ & $734.78^{\mathrm{g}}$ & $5.03^{\mathrm{f}}$ \\
\hline nWCS $(6 \%)$ & $143.69^{\mathrm{b}}$ & $581.76^{\mathrm{b}}$ & $4.05^{\mathrm{b}}$ \\
\hline aWCS & $194.05^{\mathrm{c}}$ & $574.2^{\mathrm{c}}$ & $2.96^{\mathrm{c}}$ \\
\hline atWCS & $148.5^{\mathrm{d}}$ & $606.12^{\mathrm{d}}$ & $4.08^{\mathrm{d}}$ \\
\hline pgWCS & $152.86^{\mathrm{e}}$ & $507.87^{\mathrm{e}}$ & $3.32^{\mathrm{e}}$ \\
\hline pgatWCS & $146.57^{\mathrm{f}}$ & $684.91^{\mathrm{f}}$ & $4.67^{f}$ \\
\hline pgaWCS & $145.72^{\mathrm{g}}$ & $732.3^{\mathrm{g}}$ & $5.03^{\mathrm{g}}$ \\
\hline
\end{tabular}

WCS $=$ water chestnut starch; $\mathrm{n}=$ native; $\mathrm{a}=$ acetylated; at $=$ acid-thinned; Pg = pregelatinized; Pga = pregelatinized and acetylated; Pgat $=$ pregelatinized and acid-thinned; control is without starch; mean values followed by different superscripts within the same columns are significatly different $(\mathrm{p} \leq 0.05)$. the quantity of dough baked and the amount of moisture and carbon dioxide diffused out of the loaf during baking. In this study, the bread loaves were prepared by adding different concentrations of modified water chestnut starch. It was noticed that the highest loaf weight was obtained by addition of native water chestnut starch at 3\% concentration, while the opposite effect was observed in respect of the loaf volume and specific volume. The highest loaf volume and specific volume was obtained by the addition of pgaWCS at $1 \%$ concentration. Since the bread samples studied here have been produced from the same formulation, proofing time and dough size, the difference in loaf volume could be due to different rates of gas evolution and the degree of starch gelatinization due to differences in concentrations and modifications.

The above results show that the addition of all modified WCS used in this study up to $3 \%$ concentration is enough for the highest increment of loaf weight, loaf volume and specific volume of yeast leavened bread. The effect of unmodified and modified water chestnut starch on the sensory attributes of yeast leavened breads (Table 2 -7) were significant.

Maximum mean score (7.8) was obtained by nWCS at concentration of $5 \%$ and minimum, by pgaWCS at $1 \%$ concentration with respect to taste of bread (Table 2). The results revealed that highly significant differences among different samples were found regarding the taste.

Highly significant difference was found between samples with respect to aroma of bread (Table 3). Maximum mean score (6.8) was obtained by bread containing $6 \%$

Table 2. Effect of nWCS, aWCS, atWCS, pgWCS, pgatWCS and pgaWCS at varying concentrations on taste of bread.

\begin{tabular}{lllllll}
\hline \hline & \multicolumn{6}{c}{ Concentrations } \\
\cline { 2 - 7 } Starches & $1 \%$ & $2 \%$ & $3 \%$ & $4 \%$ & $5 \%$ & $6 \%$ \\
\cline { 2 - 7 } & \multicolumn{7}{c}{ Taste } \\
\hline Control* $=5$ & & & & & \\
nWCS & $7.1^{\mathrm{a}}$ & $6^{\mathrm{a}}$ & $6^{\mathrm{a}}$ & $7.6^{\mathrm{a}}$ & 7.8 & $6.8^{\mathrm{a}}$ \\
aWCS & $6.1^{\mathrm{b}}$ & $5.1^{\mathrm{b}}$ & $6.5^{\mathrm{b}}$ & $7^{\mathrm{b}}$ & $6.3^{\mathrm{b}}$ & $7.1^{\mathrm{b}}$ \\
atWCS & $6^{\mathrm{c}}$ & $4.8^{\mathrm{c}}$ & $5.8^{\mathrm{c}}$ & $6.3^{\mathrm{c}}$ & $6.3^{\mathrm{c}}$ & $6.6^{\mathrm{c}}$ \\
pgWCS & $5.5^{\mathrm{d}}$ & $6.1^{\mathrm{d}}$ & $5.6^{\mathrm{d}}$ & $6.5^{\mathrm{d}}$ & $7^{\mathrm{d}}$ & $6.3^{\mathrm{d}}$ \\
pgatWCS & $5.8^{\mathrm{e}}$ & $5.1^{\mathrm{e}}$ & $5.5^{\mathrm{e}}$ & $6.5^{\mathrm{e}}$ & $6 . .^{\mathrm{e}} 1$ & $6^{\mathrm{e}}$ \\
pgaWCS & $4.7^{\mathrm{f}}$ & $5.7^{\mathrm{f}}$ & $5.5^{\mathrm{f}}$ & $6.7^{\mathrm{f}}$ & $6^{\mathrm{f}}$ & $7^{\mathrm{f}}$ \\
\hline \hline
\end{tabular}

${ }^{*}$ Control $=$ without starch; Assays were performed in triplicates. Mean values followed by different superscripts with in the same columns are significantly different $(\mathrm{P} \leq 0.05)$. 
pgWCS and minimum, by that with nWCS at the same concentration.

Golden brown colour of bread crust provides good product appeal which was pronouncedly affected by addition of $6 \%$ pgaWCS for the maximum score (6.5) whereas minimum mean score (4.3) was obtained by 2\% pgWCS (Table 4).

Mouth feel of bread was significantly affected by the addition of modified water chestnut starch in the wheat flour in various concentrations (Table 5). Maximum mean score (7.7) was obtained by the bread containing $6 \%$ pgaWCS, while minimum mean score (5) was obtained by that containing $1 \%$ pgaWCS.

Table 3. Effect of nWCS, aWCS, atWCS, pgWCS, pgatWCS and pgaWCS at varying concentrations on aroma of bread.

\begin{tabular}{|c|c|c|c|c|c|c|}
\hline \multirow{3}{*}{ Starches } & \multicolumn{6}{|c|}{ Concentrations } \\
\hline & $1 \%$ & $2 \%$ & $3 \%$ & $4 \%$ & $5 \%$ & $6 \%$ \\
\hline & & & \multicolumn{4}{|c|}{ Aroma } \\
\hline \multicolumn{7}{|c|}{ Control $^{*}=5$} \\
\hline WCS & $5.3^{\mathrm{a}}$ & $6^{\mathrm{a}}$ & $5^{\mathrm{a}}$ & $5.1^{\mathrm{a}}$ & $5.1^{\mathrm{a}}$ & $4.5^{\mathrm{a}}$ \\
\hline aWCS & $5.3^{\mathrm{a}}$ & $6.5^{\mathrm{b}}$ & $4.8^{\mathrm{b}}$ & $5.6^{\mathrm{b}}$ & $5.1^{\mathrm{a}}$ & $5.8^{\mathrm{b}}$ \\
\hline atWCS & $5^{\mathrm{b}}$ & $5^{\mathrm{c}}$ & $5.5^{\mathrm{c}}$ & $5.8^{\mathrm{c}}$ & $5.3^{\mathrm{b}}$ & $6.6^{\mathrm{c}}$ \\
\hline pgWCS & $4.8^{\mathrm{c}}$ & $5^{c}$ & $5.5^{\mathrm{c}}$ & $6.1^{\mathrm{d}}$ & $5.3^{\mathrm{b}}$ & $6.8^{\mathrm{d}}$ \\
\hline pgatWCS & $4.8^{\mathrm{c}}$ & $5.8^{\mathrm{d}}$ & $5.5^{\mathrm{c}}$ & $5.5^{\mathrm{e}}$ & $5.8^{\mathrm{c}}$ & $5.8^{\mathrm{b}}$ \\
\hline pgaWCS & $6^{\mathrm{d}}$ & $5.5^{\mathrm{e}}$ & $5.5^{\mathrm{c}}$ & $5.7^{\mathrm{f}}$ & $5.5^{\mathrm{d}}$ & $6.2^{\mathrm{e}}$ \\
\hline
\end{tabular}

*Control = without starch; Assays were performed in triplicates. Mean values followed by different superscripts with in the same columns are significantly different $(\mathrm{P} \leq 0.05)$.

Table 4. Effect of nWCS, aWCS, atWCS, pgWCS, pgatWCS and pgaWCS at varying concentrations on color of bread.

\begin{tabular}{lllllll}
\hline \hline & \multicolumn{6}{c}{ Concentrations } \\
\cline { 2 - 7 } Starches & $1 \%$ & $2 \%$ & $3 \%$ & $4 \%$ & $5 \%$ & $6 \%$ \\
\cline { 2 - 7 } & & \multicolumn{5}{c}{ Color } \\
\hline Control $^{*}=5$ & & & & & \\
nWCS & $5.3^{\mathrm{a}}$ & $5.3^{\mathrm{a}}$ & $5^{\mathrm{a}}$ & $5.5^{\mathrm{a}}$ & $5.1^{\mathrm{a}}$ & $5^{\mathrm{a}}$ \\
aWCS & $5.5^{\mathrm{b}}$ & $5.5^{\mathrm{b}}$ & $5.6^{\mathrm{b}}$ & $6^{\mathrm{b}}$ & $5.6^{\mathrm{b}}$ & $6.1^{\mathrm{b}}$ \\
atWCS & $5.3^{\mathrm{a}}$ & $5^{\mathrm{c}}$ & $5.1^{\mathrm{c}}$ & $5.8^{\mathrm{c}}$ & $5.6^{\mathrm{b}}$ & $6.1^{\mathrm{b}}$ \\
pgWCS & $5^{\mathrm{c}}$ & $4.3^{\mathrm{d}}$ & $5.3^{\mathrm{d}}$ & $5.5^{\mathrm{a}}$ & $5.3^{\mathrm{c}}$ & $6^{\mathrm{c}}$ \\
pgatWCS & $5.3^{\mathrm{a}}$ & $6.1^{\mathrm{e}}$ & $5.5^{\mathrm{e}}$ & $5.5^{\mathrm{a}}$ & $5.8^{\mathrm{d}}$ & $5.6^{\mathrm{d}}$ \\
pgaWCS & $4.7^{\mathrm{d}}$ & $5.2^{\mathrm{f}}$ & $5^{\mathrm{a}}$ & $5^{\mathrm{d}}$ & $5.2^{\mathrm{e}}$ & $6.5^{\mathrm{e}}$ \\
\hline \hline
\end{tabular}

*Control = without starch; Assays were performed in triplicates. Mean values followed by different superscripts with in the same columns are significantly different $(\mathrm{P} \leq 0.05)$.
Mean values of surface appearance scores have been shown in Table 6 . Bread containing 5\% pgatWCS scored maximum points (7.3) and that containing $2 \%$ pgWCS scored minimum points (4.5).

Bread samples were assessed for texture and the results (Table 7) showed that the maximum mean score (7.5) was obtained by bread containing 5\% pgatWCS and minimum mean score (4) by that containing $5 \%$ aWCS.

Thus, it was concluded that the sensory properties of yeast leavened bread improved, with the addition of native and modified water chestnut starch at certain levels.

Table 5. Effect of nWCS, aWCS, atWCS, pgWCS, pgatWCS and pgaWCS at varying concentrations on mouth feel of bread.

\begin{tabular}{lllllll}
\hline \hline & \multicolumn{7}{c}{ Concentrations } \\
\cline { 2 - 7 } Starches & $1 \%$ & $2 \%$ & $3 \%$ & $4 \%$ & $5 \%$ & $6 \%$ \\
\cline { 2 - 7 } & & \multicolumn{7}{c}{ Mouth feel } \\
\hline Control $^{*}=5$ & & & & & \\
nWCS & $5.8^{\mathrm{a}}$ & $5.8^{\mathrm{a}}$ & $5.3^{\mathrm{a}}$ & $7.5^{\mathrm{a}}$ & $7.5^{\mathrm{a}}$ & $6^{\mathrm{a}}$ \\
aWCS & $5.3^{\mathrm{b}}$ & $5.1^{\mathrm{b}}$ & $6.3^{\mathrm{b}}$ & $6.6^{\mathrm{b}}$ & $6.1^{\mathrm{b}}$ & $6.3^{\mathrm{b}}$ \\
atWCS & $6.1^{\mathrm{c}}$ & $5.1^{\mathrm{b}}$ & $6^{\mathrm{c}}$ & $6.3^{\mathrm{c}}$ & $5.8^{\mathrm{c}}$ & $6.8^{\mathrm{c}}$ \\
pgWCS & $5.6^{\mathrm{d}}$ & $6.3^{\mathrm{c}}$ & $5.5^{\mathrm{d}}$ & $6.3^{\mathrm{c}}$ & $7.1^{\mathrm{d}}$ & $6.8^{\mathrm{c}}$ \\
pgatWCS & $5.8^{\mathrm{a}}$ & $5.8^{\mathrm{d}}$ & $6.8^{\mathrm{e}}$ & $7.3^{\mathrm{d}}$ & $6.8^{\mathrm{e}}$ & $7.1^{\mathrm{d}}$ \\
pgaWCS & $5^{\mathrm{e}}$ & $5.5^{\mathrm{e}}$ & $5.7^{\mathrm{f}}$ & $6.7^{\mathrm{e}}$ & $6.2^{\mathrm{f}}$ & $7.7^{\mathrm{e}}$ \\
\hline \hline
\end{tabular}

*Control = without starch; Assays were performed in triplicates Mean values followed by different superscripts with in the same columns are significantly different $(\mathrm{P} \leq 0.05)$.

Table 6. Effect of nWCS, aWCS, atWCS, pgWCS, pgatWCS and pgaWCS at varying concentrations on surface appearance of bread.

\begin{tabular}{lllllll}
\hline \hline & \multicolumn{6}{c}{ Concentrations } \\
\cline { 2 - 7 } Starches & $1 \%$ & $2 \%$ & $3 \%$ & $4 \%$ & $5 \%$ & $6 \%$ \\
\cline { 2 - 7 } & \multicolumn{6}{c}{ Surface Appearance } \\
\hline Control ${ }^{*}=5$ & & & & & \\
nWCS & $6.3^{\mathrm{a}}$ & $5^{\mathrm{a}}$ & $5.3^{\mathrm{a}}$ & $6^{\mathrm{a}}$ & $6.8^{\mathrm{a}}$ & $4.8^{\mathrm{a}}$ \\
aWCS & $5^{\mathrm{b}}$ & $5.8^{\mathrm{b}}$ & $5.5^{\mathrm{b}}$ & $7^{\mathrm{b}}$ & $4.3^{\mathrm{b}}$ & $6.5^{\mathrm{b}}$ \\
atWCS & $5^{\mathrm{b}}$ & $5.3^{\mathrm{c}}$ & $5.6^{\mathrm{c}}$ & $6.6^{\mathrm{c}}$ & $6.5^{\mathrm{c}}$ & $6.6^{\mathrm{c}}$ \\
pgWCS & $5.5^{\mathrm{c}}$ & $4.5^{\mathrm{d}}$ & $5^{\mathrm{d}}$ & $5.6^{\mathrm{d}}$ & $5.6^{\mathrm{d}}$ & $6^{\mathrm{d}}$ \\
pgatWCS & $5.6^{\mathrm{d}}$ & $7.1^{\mathrm{e}}$ & $6.6^{\mathrm{e}}$ & $7.1^{\mathrm{e}}$ & $7.3^{\mathrm{e}}$ & $7^{\mathrm{e}}$ \\
pgaWCS & $4.5^{\mathrm{e}}$ & $4.7^{\mathrm{f}}$ & $5.2^{\mathrm{f}}$ & $6.5^{\mathrm{f}}$ & $4.5^{\mathrm{f}}$ & $6.2^{\mathrm{f}}$ \\
\hline \hline
\end{tabular}

*Control = without starch; Assays were performed in triplicates. Mean values followed by different superscripts with in the same columns are significantly different $(\mathrm{P} \leq 0.05)$. 
Table 7. Effect of nWCS, aWCS, atWCS, pgWCS, pgatWCS and pgaWCS at varying concentrations on texture of bread.

\begin{tabular}{lllllll}
\hline \hline \multirow{2}{*}{ Starches } & \multicolumn{6}{c}{ Concentrations } \\
\cline { 2 - 7 } & $1 \%$ & $2 \%$ & $3 \%$ & $4 \%$ & $5 \%$ & $6 \%$ \\
\cline { 2 - 7 } Control* $^{*}=5$ & & \multicolumn{5}{c}{ Texture } \\
nWCS & $6.3^{\mathrm{a}}$ & $6^{\mathrm{a}}$ & $5.6^{\mathrm{a}}$ & $6.3^{\mathrm{a}}$ & $6.8^{\mathrm{a}}$ & $5.8^{\mathrm{a}}$ \\
aWCS & $5^{\mathrm{b}}$ & $5.6^{\mathrm{b}}$ & $5.5^{\mathrm{b}}$ & $5.8^{\mathrm{b}}$ & $4^{\mathrm{b}}$ & $6^{\mathrm{b}}$ \\
atWCS & $5.5^{\mathrm{c}}$ & $5.3^{\mathrm{c}}$ & $5.6^{\mathrm{a}}$ & $6.3^{\mathrm{a}}$ & $7^{\mathrm{c}}$ & $7.3^{\mathrm{c}}$ \\
pgWCS & $5.1^{\mathrm{d}}$ & $5.3^{\mathrm{c}}$ & $4.6^{\mathrm{c}}$ & $5.6^{\mathrm{c}}$ & $5.5^{\mathrm{d}}$ & $6.3^{\mathrm{d}}$ \\
pgatWCS & $5.6^{\mathrm{e}}$ & $7.1^{\mathrm{d}}$ & $6.6^{\mathrm{d}}$ & $6.8^{\mathrm{d}}$ & $7.5^{\mathrm{e}}$ & $7.1^{\mathrm{e}}$ \\
pgaWCS & $5^{\mathrm{b}}$ & $5^{\mathrm{e}}$ & $5.5^{\mathrm{b}}$ & $7^{\mathrm{e}}$ & $6^{\mathrm{f}}$ & $6.5^{\mathrm{f}}$ \\
\hline \hline
\end{tabular}

*Control = without starch; Assays were performed in triplicates. Mean values followed by different superscripts with in the same columns are significantly different $(\mathrm{P} \leq 0.05)$.

\section{References}

AACC International 2000. Approved Methods of the American Association of Cereal Chemists. $10^{\text {th }}$ edition. Methods 08-01, 10-10B, 30-10, 38-10, 4414A, 54-21 and 61-03. The Association; St. Paul, Minnesota, USA.

AOAC 2000. Official Methods of Analysis of AOAC International, $17^{\text {th }}$ edition, Vol: II, William Horwitz (ed.), AOAC International, Gaithersberg, MD, USA.

BeMiller, J. N. 1997. Starch modification: Challenges and prospects. Starch, 49: 127-131.

Glover, J.M., Walker, C.E., Mattern, P.J. 2006. Functionality of sorghum flour components in a high ratio cake. Journal of Food Science, 51: 1280-1283.

Hizukuri, S., Takeda, Y., Shitaozono, T., Abe, J., Ohtakara, A., Takeda, C., Suzuki, A. 1988. Structure and properties of water chestnut (Trapa natans L. var. bispinosa Makino) starch. Starch/Starke, 40: 165-171.

Lawal, O.S. 2004. Composition, physico-chemical properties and retrogradation characteristics of native, oxidized, acetylated and acid-thinned new cocoyam (Xanthosoma sagittifolium) starch. Food Chemistry, 87: 205-218.

Lutfi, Z., Hasnain, A. 2009. Effect of modified water chestnut (Trapa bispinosa) starch on physical and sensory properties of sponge cakes. Pakistan Journal of Scientific and Industrial Research, 52: 146-150.

Ragaee, S., Abdel-Aal, E.S.M. 2006. Pasting properties of starch and protein in selected cereals and quality of their products. Food Chemistry, 95: 9-18.

Sathe, S.K., Salunkhe, D.K. 1981. Isolation, partial characterization and modification of the great northern bean (Phaseolus vulgaris L.) starch. Journal of Food Science, 46: 617-621.

Sira, E.E.P., Amaiz, M.L. 2004. A laboratory scale method for isolation of starch from pigmented sorghum. Journal of Food Engineering, 64: 515-519.

Stear, C. A. 1990. Effects of dough additives. In: Handbook of Breadmaking Technology, pp. 2759, Elsevier Science Publishers Ltd., New York, USA.

Tulyathan, V., Boondee, K., Mahawanich, T. 2005. Characteristics of starch from water chestnut (Trapa bispinsa Roxb.). Journal of Food Biochemistry, 29: 337-348.

Waliszewski, K.N., Aparicio, M.A., Bello, L.A., Monroy, J.A. 2003. Changes of banana starch by chemical and physical modification. Carbohydrate Polymers, 52: 237-242.

Zghal, M.C., Scanlon, M.G., Sapirstein, H.D. 2002. Cellular structure of bread crumb and its influence on mechanical properties. Journal of Cereal Science, 36: $167-176$.

Zobel, H.F. 1984. Gelatinization of starch and mechanical properties of starch pastes. In: Starch Chemistry and Technology, R.L. Whistler, J.N. Bemiller and E.F. Paschall (eds.), pp. 291-293, Academic Press, NewYork, USA. 